\title{
Strain differences in light-contingent barpress behavior of the rat
}

\author{
GORDON M. HARRINGTON \\ University of Northern Iowa, Cedar Falls, Iowa 50613
}

\begin{abstract}
Leverpress response rates to light-onset reinforcement were obtained for 480 rats from 12 inbred strains: ACI, A990, A35322, F344, INR, IR, MNR/Har, MNRA, MR/Har, TS1, TS3, WAG. The results provide parametric data for methodological use and add to the standardization of these strains as behaviorally defined lines. No relationship was found between response rate and eye pigmentation.
\end{abstract}

Girdner (1953) was the first to show that rats would acquire a barpress response for onset of light. This effect was first confirmed by Henderson (1957), part of whose data had been published earlier with other confirmations (Marx, Henderson, \& Roberts, 1955). In a well designed study, Lockard (1962) examined differences between albino and hooded stocks of rats provided with leverpress control of illumination levels. The nature of the differences found was not readily explainable, nor was it clear whether the effects should be attributed to eye pigmentation or to some other genetic factor differentiating the stocks.

In an unpublished 1961 study, I obtained a very clear-cut correlation between light-conditioned barpress rate and eye color, using three stocks at three levels of pigmentation. The results were so strongly supportive of my own theory as to suggest they might better be attributed to accidental correlation with other variables differentiating the stocks. A search for stocks similar in eye pigmentation but differing on other variables was frustrated by lack of any standardization data appropriate for design of behavioral experiments. This is one of a number of studies (Harrington, 1971a, 1971b, 1972, 1979a, 1979b, 1979c, 1979d, $1979 \mathrm{e}, 1979 \mathrm{f}, 1979 \mathrm{~g}, 1979 \mathrm{~h}$; Harrington \& Hellwig, 1979a, 1979b) that eventuated, cataloging the characteristics of those 12 genetically defined strains of laboratory rat most frequently cited in the psychological literature. Here, the strains' characteristics are examined for the behavior that originally stimulated this program: light-conditioned barpress. It can be noted that similar needs for standardization have also influenced methodological development in other disciplines (International Committee on Laboratory Animals, 1971).

\section{METHOD}

\section{Subjects}

Subjects were 480 rats, $75-89$ days of age, 20 animals of each sex within each of the following 12 inbred strains: $\mathrm{ACI} / \mathrm{Har}$, A990/Har, A35322/Har, F344/DuHar, INR, IR, MNR/Har, MNRA (formerly MNR-a/Har), MR/Har, TS1, TS3, WAG/Har.
All lines are designated by the standard nomenclature for this species and are described in the fourth international listing (Festing \& Staats, 1973). Animals were bred and maintained at $25.5^{\circ} \mathrm{C} \pm 1.1^{\circ} \mathrm{C}$ and $40 \% \pm 5 \%$ relative humidity. Breeders and pups were housed under natural light cycle. Pups were handled for $1 \mathrm{~min}$ on alternate days from age 14 to 45 days. At 45 days, they were transferred to individual cages with 24-h light cycle. More detailed descriptions are available elsewhere (Harrington, 1968).

\section{Apparatus and Procedure}

Each animal was preadapted to a Lehigh Valley Electronics 1416 operant conditioning chamber, with apparatus houselight illumination, for $1,000 \mathrm{sec} /$ day for 5 days. Following adaptation, animals were tested in five daily sessions of $1,000 \mathrm{sec}$ each. Under test conditions, the houselight was extinguished and a leverpress illuminated the stimulus light above the lever for the duration of the press. Responses were automatically recorded and filed with a data acquisition system.

\section{RESULTS AND DISCUSSION}

The means and standard deviations of the total number of barpresses over the five daily test sessions are displayed for each of the 12 strains in Table 1 . No

Table 1

Barpress Response Rate to Light Onset for 12 Inbred Strains of Rats

\begin{tabular}{lrrrrr}
\hline & \multicolumn{4}{c}{ Response Rate* } \\
\cline { 2 - 3 } \multicolumn{1}{c}{ Strain } & Mean & SD & & Mean & SD \\
\cline { 2 - 3 } \cline { 5 - 6 } ACI/Har & 52.8 & 62.6 & 89.3 & 84.0 \\
A990/Har & 127.0 & 98.6 & 95.7 & 93.4 \\
A35322/Har & 96.5 & 81.2 & 115.5 & 89.8 \\
F344/DuHar & 54.1 & 49.9 & 65.6 & 57.2 \\
INR & 165.6 & 68.2 & 195.3 & 73.9 \\
IR & 6.1 & 8.8 & 7.2 & 14.7 \\
MNR/Har & 81.8 & 57.7 & 54.8 & 54.8 \\
MNRA & 100.0 & 44.3 & 81.4 & 53.8 \\
MR/Har & 51.3 & 41.9 & 56.3 & 33.9 \\
TS1 & 16.7 & 27.5 & 15.4 & 29.2 \\
TS3 & 107.7 & 93.7 & 112.5 & 107.2 \\
WAG/Har & 101.9 & 68.2 & 109.9 & 64.6 \\
\hline
\end{tabular}

Note $-N=20$ for each sex within each strain.

*Barpresses per 5 days for 1,000 sec/day. 
relationship between light response rate and eye pigmentation is discernible in these data. For experiments where differentiation on light-conditioned barpress rate might be useful, INR or possibly A990 would be indicated animals of preference where high rate was desired and IR or TS1 for low rate. A majority of the strains show relatively high light-conditioned barpress rates, although INR shows the highest. Where a high rate might be useful in experimental design, one could therefore choose INR or alternatively, on the basis of other variables, from among A990, A35322, MNRA, TS3, and WAG. For low response rate, IR or TS1 would be indicated.

In an era of increasing sensitivity to ethical issues in animal experimentation, light response does not raise any of the questions of humane care that arise in use of food deprivation or shock. While in most research applications, tissue need or aversive stimulation conditions are necessary, light-contingent barpressing can provide a useful laboratory exercise in or demonstration of operant behavior for lower level students or the public.

\section{REFERENCES}

Festing, M., \& StaAts, J. Standardized nomenclature for inbred strains of rats. Transplantation, 1973, 16, 221-245.

GIRDNER, J. B. An experimental analysis of the behavioral effects of a perceptual consequence unrelated to organic drive states. American Psychologist, 1953, 8, 354-355.

HARRINGTON, G. M. Genetic-environmental interaction in "intelligence." I: Biometric genetic analysis of maze performance of Rattus Norvegicus. Developmental Psychobiology, 1968, 1, 211-218.

HARRINGTON, G. M. Strain differences among rats initiating exploration of differing environments. Psychonomic Science, 1971, 23, 348-349. (a)

HARrington, G. M. Strain differences in rotating wheel activity of the rat. Psychonomic Science, 1971, 23, 363-364. (b)

HARRINGton, G. M. Strain differences in open field behavior of the rat. Psychonomic Science, 1972, 27, 51-53.

HARRINGTon, G. M. Strain differences in activity of the rat in a shuttle stabilimeter. Bulletin of the Psychonomic Society, 1979, 13, 149-150. (a)

HARRINGton, G. M. Strain differences in activity of the rat using a home cage stabilimeter. Bulletin of the Psychonomic Society, 1979, 13, 151-152. (b)

HARRington, G. M. Strain differences in free operant leverpress levels in the rat. Bulletin of the Psychonomic Society, 1979, 13, 153-154. (c)

HARRINGton, G. M. Strain differences in open-field behavior of the rat. II. Bulletin of the Psychonomic Society, 1979, 13, 85-86. (d)

HARrington, G. M. Strain differences in passive avoidance conditioning in the rat. Bulletin of the Psychonomic Society, 1979, 13, 157-158. (e)

HARRINGton, G. M. Strain differences in runway learning in the rat. Bulletin of the Psychonomic Society, 1979, 13, 159-160. (f)

HARrington, G. M. Strain differences in shuttle avoidance conditioning in the rat. Bulletin of the Psychonomic Society, 1979, 13, 161-162. (g)

HARRINGTON, G. M. Strain differences in simple operant barpress acquisition to an auditory stimulus by rats. Bulletin of the Psychonomic Society, 1979, 13, 163-164. (h)

HarRington, G. M., \& Hellwig, L. R. Strain differences in basal metabolism of behaviorally defined rats. Bulletin of the Psychonomic Society, 1979, 13, 165-166. (a)

Harrington, G. M., \& Hellwig, L. R. Strain differences in organ weights of behaviorally defined rats. Bulletin of the Psychonomic Society, 1979, 13, 167-169. (b)

Henderson, R. L. Stimulus-intensity dynamism and secondary reinforcement. Journal of Comparative and Physiological Psychology, 1957, 50, 339-344.

International Commitee on Laboratory Animals. Defining the laboratory animal. Washington, D.C: National Academy of Sciences, 1971.

LOCKARD, R. B. Some effects of maintenance luminance and strain differences upon self-exposure to light by rats. Journal of Comparative and Physiological Psychology, 1962, 55, 1118-1123.

Marx, M. H., Henderson, R. L., \& Roberts, C. L. Positive reinforcement of the bar pressing response by a light stimulus following dark operant pretests with no aftereffect. Journal of Comparative and Physiological Psychology, 1955, 48, 73-75.

(Received for publication January 16, 1979.) 